\title{
Genetic Regulation of Virulence and Antibiotic Resistance in Acinetobacter baumannii
}

\author{
Carsten Kröger ${ }^{1, *}$, Stefani C. Kary ${ }^{1}$, Kristina Schauer ${ }^{2}$ and Andrew D. S. Cameron ${ }^{3}$ \\ 1 Department of Microbiology, School of Genetics and Microbiology, Moyne Institute of Preventive Medicine, \\ Trinity College Dublin, Dublin 2, Ireland; karys@tcd.ie \\ 2 Department of Veterinary Science, Faculty of Veterinary Medicine, Ludwig-Maximilians-Universität München, \\ Oberschleißheim 85764, Germany; kristina.schauer@mh.vetmed.uni-muenchen.de \\ 3 Department of Biology, University of Regina, Regina, SK S4S 042, Canada; andrew.cameron@uregina.ca \\ * Correspondence: carsten.kroeger@tcd.ie; Tel.: +353-1-896-1414
}

Academic Editor: Helen J. Wing

Received: 22 September 2016; Accepted: 20 December 2016; Published: 28 December 2016

\begin{abstract}
Multidrug resistant microorganisms are forecast to become the single biggest challenge to medical care in the 21st century. Over the last decades, members of the genus Acinetobacter have emerged as bacterial opportunistic pathogens, in particular as challenging nosocomial pathogens because of the rapid evolution of antimicrobial resistances. Although we lack fundamental biological insight into virulence mechanisms, an increasing number of researchers are working to identify virulence factors and to study antibiotic resistance. Here, we review current knowledge regarding the regulation of virulence genes and antibiotic resistance in Acinetobacter baumannii. A survey of the two-component systems AdeRS, BaeSR, GacSA and PmrAB explains how each contributes to antibiotic resistance and virulence gene expression, while BfmRS regulates cell envelope structures important for pathogen persistence. A. baumannii uses the transcription factors Fur and Zur to sense iron or zinc depletion and upregulate genes for metal scavenging as a critical survival tool in an animal host. Quorum sensing, nucleoid-associated proteins, and non-classical transcription factors such as AtfA and small regulatory RNAs are discussed in the context of virulence and antibiotic resistance.
\end{abstract}

Keywords: Acinetobacter baumannii; virulence gene regulation; two-component systems; multidrug efflux pumps; metal acquisition; antibiotic resistance

\section{Introduction}

Bacterial infections are a leading cause of death worldwide, and the fading age of antibiotics increases risks associated with basic healthcare and surgeries. Moreover, the continuous emergence of multidrug resistant (MDR) microorganisms is a major economic burden, yet the development of new antimicrobials has stalled [1,2]. The most prominent MDR bacterial genera currently evading antimicrobial treatment and spreading worldwide as nosocomial pathogens have been dubbed the ESKAPE organisms [2-4]: Enterococcus faecium, Staphylococcus aureus, Klebsiella pneumoniae, Acinetobacter baumannii, Pseudomonas aeruginosa and Enterobacter species. Notably, infections caused by the Gram-negative coccobacillus Acinetobacter baumannii are growing in number in hospitals around the world [5-9]. The genus Acinetobacter belongs to the class Gamma-proteobacteria, the order Pseudomonadales, and the family Moraxellaceae. Only a few members of this genus have a history of infecting humans, of which A. baumannii, A. pittii and A. nosocomialis are the most clinically relevant [10,11], while many other Acinetobacter species are non-pathogenic. Infections of humans are mostly, but not exclusively, hospital-acquired. Community-acquired infection with $A$. baumannii is rare and often occurs in predisposed individuals, mostly in tropical regions [12]. Predisposing factors may include diabetes, chronic lung conditions or post-trauma and adverse lifestyles, such as alcohol abuse and smoking [13]. 
In the United States, A. baumannii is now responsible for more than $10 \%$ of nosocomial infections [14]. Critically ill patients, including intensive care unit patients, are at a particularly high risk of infection by A. baumannii. The bacterium causes a variety of diseases such as ventilator-associated pneumonia (VAP), bacteraemia, skin and soft tissue infections, endocarditis, urinary tract infections and meningitis $[6,10]$. The mortality rate in patients is debated, but it can reach up to $35 \%$ or even higher $[7,15]$ and likely depends on a patient's individual condition and the A. baumannii strain. Carbapenem-resistant $A$. baumannii (CRAB) strains in particular have emerged as one of the most concerning antibiotic-resistant pathogens [16]. Based on recent estimates, over $50 \%$ of $A$. baumannii isolates from intensive care units are carbapenem-resistant, and therapy of CRAB infections is estimated to cost global healthcare systems in excess of 742 million US Dollars annually [17]. Of particular concern is the isolation of pan-resistant A. baumannii strains across the world, illustrating the ongoing emergence of increasingly dangerous isolates [18-23].

To successfully combat the spread of MDR bacterial pathogens, we must develop sufficient biological understanding to engineer new and effective interventions. Despite the growing clinical importance of pathogenic strains of $A$. baumannii, the scientific community has only begun to understand the fundamentals of $A$. baumannii infection biology. A number of studies have identified virulence factors, from extracellular matrices and biofilm formation to drug efflux pumps. For example, the impact of cell surface-associated virulence factors and secretion systems on cell-host interaction has been reviewed recently [24].

A next step is to understand the mechanisms that control expression of virulence factors, because bacteria must carefully control gene expression to ensure correct spatiotemporal production. Regulated expression integrates virulence factors into cellular physiology and reflects how the pathogen is sensing and interacting with host-associated environments and other niches. To combat antibiotic resistance and develop knowledge-based interventions, detailed understanding of the resistance mechanisms and the regulation of genes conferring drug resistance are required. In this review, we provide an overview of current knowledge of the protein and RNA transcription factors that control virulence gene expression and antibiotic resistance in A. baumannii, followed by a brief discussion of research horizons that promise important insights into $A$. baumannii virulence.

\section{Two-Component Systems}

Two-component systems (TCS) are ubiquitous systems of signal transduction in bacteria [25]. A typical TCS is composed of a sensor kinase embedded in the cytoplasmic membrane that is able to sense and respond to extracellular and/or intracellular features, like osmotic pressure or $\mathrm{pH}$ [26]. When triggered by the environmental or physiological stimulus, the sensor kinase relays this signal by phosphorylating a cognate response regulator. The response regulator is a transcription factor that undergoes a conformational change upon phosphorylation that facilitates (or in some cases hinders) DNA-binding. Using adenosine triphosphate (ATP), the sensor kinases autophosphorylates at a histidine residue which can be transferred onto an aspartic acid residue of the response regulator, usually leading to a transcriptional response (activation and/or repression). When the stimulus ceases, the phosphorelay system runs in reverse wherein the sensor kinase dephosphorylates the response regulator and reverses the transcriptional response.

Although TCS can be highly conserved between species, the regulons they control can differ even among closely related species $[27,28]$. Also emerging is an appreciation that both the phosphorylated and unphosphorylated forms of the response regulator can control different regulons. An example is the SsrB protein in Salmonella, which activates virulence genes as phosphorylated form and biofilm formation in an unphosphorylated state [29,30]. In A. baumannii AB5075-UW, 10 sensor kinases and 17 response regulators are annotated [31]. This is an average number of response regulators for pathogenic bacteria, but lower than the average of 40 in Escherichia coli and around 90 in the more closely related Pseudomonas [32]. The excess of response regulators highlights the potential for cross-talk among TCS. Five TCS have been studied in Acinetobacter (Table 1), and a simple schematic of 
the regulators and their virulence gene targets is provided in Figure 1. Of these, four TCS are conserved in 15 sequenced A. baumannii and one A. baylyi genomes provided at the Prokaryotic Genome Analysis Tool webserver (http:/ / tools.uwgenomics.org/pgat/) [33], whereas adeRS is missing from A. baumannii SDF and A. baylyi ADP1.

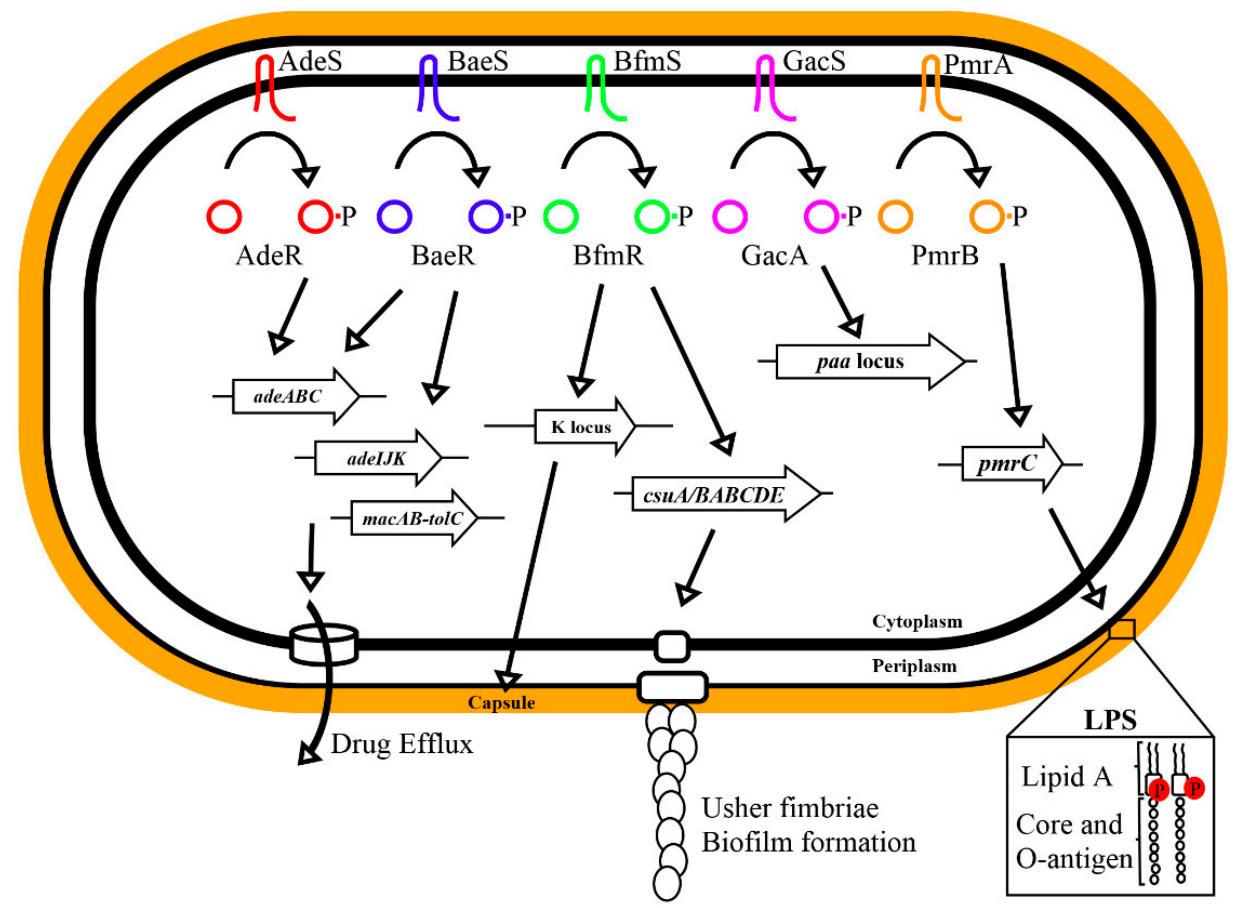

Figure 1. Overview of the impact of five Acinetobacter baumannii two-component systems on gene expression of selected genomic loci. LPS: lipopolysaccharide.

\subsection{AdeRS}

The adeRS TCS is the best characterized regulatory system in A. baumannii. Most notably, it controls the expression of the RND-type efflux pump AdeABC [34,35]. Deletion of adeR or adeS led to increased susceptibility towards aminoglycosides [35]. Many studies have connected antibiotic resistance to increased production of AdeABC, e.g., resistance to tigecycline, fluoroquinolones, aminoglycosides and others [36,37]. Decreased susceptibility was reported to be caused by mutations in adeRS which led to overexpression of $a d e A B C$ [38-41]. Moreover, adeRS shows a high level of sequence variation in clinical isolates which could explain the differences in tigecycline resistance [42]. The regulation of ade $A B C$ is complex and not only controlled by AdeRS, as overexpression of the efflux pump was also observed in a strain lacking insertion mutations in adeRS that cause overexpression of the system [43]. The overexpression of AdeABC led to increased virulence in a pulmonary infection model, which suggests that increased levels of Ade $A B C$ are beneficial to both antibiotic resistance and in vivo fitness, and can explain why adeRS mutations are frequently observed in clinical isolates [43-46]. However, the AdeRS regulon includes many other genes that contribute to virulence as recently reported using RNA-seq [47]. It was found that AdeRS directly or indirectly regulates 579 genes, most notably those involved in the expression of efflux pumps, biofilm formation and virulence in a Galleria mellonella larvae infection model. Intriguingly, some outcomes of the AdeRS deletion appeared to be strain specific. Deletion of adeRS in A. baumannii AYE resulted in loss of biofilm formation in an ex vivo porcine vaginal mucosa model and a reduced host epithelial cell toxicity, but not in A. baumannii S1 [47]. Strain to strain variation in a key feature such as antimicrobial resistance highlights the difficulty of extrapolating a significant biological finding between strains [42,48]. This diversity among A. baumannii strains makes treatment even more challenging [49]. 


\subsection{BaeSR}

The baeSR TCS in Acinetobacter spp. was so named because the nucleotide sequence indicated high similarity to baeSR in E. coli and to Salmonella enterica serovar Typhimurium [50]. Among other genes, BaeSR controls drug efflux pumps in E. coli, which suggested a similar function for A. baumannii. Indeed, deletion of baeSR led to significantly reduced expression of the major efflux pumps AdeABC, AdeIJK, and MacAB-TolC, resulting in increased susceptibility to tigecycline [50,51]. The regulation of the three efflux pumps is proposed to be indirect, though, as purified BaeR-His did not bind the promoters of $a d e A$, adeI or macA in electrophoretic mobility shift assays. However, it was unclear whether the phosphorylation state of purified BaeR-His was appropriate for DNA binding, or whether the histidine tag might interfere with DNA binding. As the regulons of AdeRS and BaeSR overlap, this could also mean that BaeSR functions through cross-talk with AdeRS. The expression of baeSR increased upon growth in elevated sucrose levels, suggesting that BaeS responds to changes in osmotic pressure [50]. In addition, tannic acid which showed potential as an antibiotic adjuvant [52,53], increased gene expression of the three efflux pumps mentioned above [51].

\subsection{BfmRS}

The ability to form biofilms on abiotic surfaces allows A. baumannii to resist adverse conditions, such as desiccation or detergents. Protein filaments called pili are required for attachment to surfaces. In A. baumannii, the best studied pili involved in biofilm formation are produced by the $c s u A / B A B C D E$ usher-chaperone assembly system, which is regulated by the TCS termed $b f m R S$ [54,55]. Deletion of only the response regulator $b f m R$ resulted in complete loss of biofilm formation on plastic, while a $b f m S$ sensor kinase mutant retained some ability to from biofilm, suggesting that $\mathrm{BfmR}$ can be activated by alternate sensor kinases [54]. Whether $c s u A / B A B C D E$ is required for attachment to host tissues is not fully resolved. $c s u A / B A B C D E$ is not involved in adherence to bronchial epithelial cells [56], but deletion of the sensor kinase $b f m S$ led a loss of adhesion to A549 human alveolar epithelial cells [57]. However, adhesion to A549 could be independent of $c s u A / B A B C D E$, if BfmRS controls the regulation of other adhesion factors.

BfmRS both enhances and represses antibiotic resistance. Deletion of $b f m S$ led to an increased minimum inhibitory concentration (MIC) of ciprofloxacin and a decreased MIC of imipenem, while deletion of $b f m R$ increased the MIC of meropenem and colistin [58]. Moreover, outer membrane proteins, such as the major virulence factor OmpA, were increasingly released into the supernatant, indicating that cellular integrity is compromised. Indeed, BfmRS regulates genes that maintain cellular morphology and control cell division-the direct targets are however unknown [54]. Recently, BfmRS was shown to control gene expression of the $\mathrm{K}$ locus, a major virulence determinant in A. baumannii ATCC17978, which harbors genes for exopolysaccharide (e.g., capsule) production [59]. Surprisingly, capsule synthesis was not affected in deletions of $b f m R$ in two clinical isolates that showed reduced growth/survival in human ascites' fluid and serum [58]. These diverse phenotypes highlight the multifaceted nature of the BfmRS regulon. Unfortunately, we lack a detailed understanding of the regulon in biofilm-inducing conditions, in an infection model, or a description of strain-specific differences in regulon membership. As BfmR was recently suggested as a candidate drug target, deeper knowledge of the regulon of the BfmRS TCS is therefore of particular interest [58].

\subsection{GacSA}

The GacS sensor kinase was identified through its mutagenesis in a transposon screen of A. baumannii ATCC19606; the mutant was unable to use citrate as a sole carbon source [60] and to kill the human fungal pathogen Candida albicans [61]. Today, the gacSA TCS is established as a global regulator in A. baumannii controlling the expression of 674 genes including virulence genes, biofilm and pili formation, resistance against human serum, motility, and metabolism of aromatic compounds [62,63]. Deletion of GacS led to an avirulent phenotype in a mouse septicaemia model 
and greatly reduced bacterial load in spleen, kidney and liver 12 hours after infection, highlighting the importance of GacS during systemic infection. Intriguingly, GacS controls a catabolic pathway of aromatic compounds (termed paa, phenylactetic acid pathway) that was shown to be important for full virulence. Genome comparisons revealed that the A. baumannii paa operon is similar to the well-studied paa system in E. coli $[62,64]$. The aromatic compounds phenylacetate and phenylalanine are converted into acetyl- and succinyl-CoA and fed into the tricarboxylic acid cycle. Surprisingly, inhibition of the paa pathway led to increased killing of $A$. baumannii in a zebrafish infection model. The metabolic by-product phenylacetate accumulates in the gacS mutant and represents a potent chemoattractant for neutrophils, thus GacS is involved in innate immune evasion by controlling the expression of the paa locus [63]. The GacSA TCS is not a contiguous operon as each gene is located far apart on the chromosome, unlike the AdeRS, BaeSR, PmrAB and BfmRS TCS in A. baumannii. Whereas GacS is alone in a transcriptional unit, the response regulator GacA does lie adjacent to another sensor kinase of unknown function (A1S_0235 in A. baumannii ATCC17978), suggesting that GacS has co-opted a response regulator to create cross-talk between two TCS.

Table 1. Best characterized regulatory systems in Acinetobacter baumannii.

\begin{tabular}{|c|c|c|c|}
\hline $\begin{array}{l}\text { Gene } \\
\text { Name }\end{array}$ & Type & Function and Phenotype & $\begin{array}{l}\text { Relevant } \\
\text { References }\end{array}$ \\
\hline adeRS & Two-component system & $\begin{array}{l}\text { Directly or indirectly controls } 579 \text { genes. Regulates the expression } \\
\text { of the AdeABC drug efflux pump. Required for } \\
\text { biofilm formation biofilm. }\end{array}$ & {$[35,47]$} \\
\hline$b f m R S$ & Two-component system & $\begin{array}{l}\text { Controls the expression of the K locus (exopolysaccharide } \\
\text { production/capsule). Regulates expression of CsuA/BABCDE } \\
\text { chaperone-usher secretion system, biofilm formation on } \\
\text { abiotic surfaces. }\end{array}$ & {$[54,58,59]$} \\
\hline $\operatorname{gacSA}$ & Two-component system & $\begin{array}{l}\text { Directly or indirectly controls } 674 \text { genes, including virulence } \\
\text { genes, biofilm and pili formation, resistance against human serum, } \\
\text { motility, and metabolism of aromatic compounds (paa locus). }\end{array}$ & {$[60,62,63]$} \\
\hline baeSR & Two-component system & $\begin{array}{l}\text { Deletion results in reduced expression of AdeABC, AdeIJK, } \\
\text { MacAB-TolC drug efflux pumps and increases susceptibility to } \\
\text { tannic acid. }\end{array}$ & {$[50,51]$} \\
\hline fur & Transcription factor & Transcriptional repressor of genes involved in iron homeostasis. & {$[66]$} \\
\hline$z u r$ & Transcription factor & Transcriptional repressor of genes involved in zinc homeostasis. & {$[67,68]$} \\
\hline$a b a R$ & Transcription factor & $\begin{array}{l}\text { AHL-responsive transcription factor involved in quorum sensing } \\
\text { and biofilm formation. }\end{array}$ & {$[69,70]$} \\
\hline $\operatorname{atf} A$ & $\begin{array}{l}\text { RNA polymerase } \\
\text { binding protein }\end{array}$ & $\begin{array}{l}\text { Deletion of atfA results in cell enlargement, loss of biofilm } \\
\text { formation and increased susceptibility to antibiotics and ethanol. }\end{array}$ & {$[71]$} \\
\hline hns & $\begin{array}{l}\text { Nucleoid-associated } \\
\text { protein }\end{array}$ & $\begin{array}{l}\text { Deletion results in a hyper-motile phenotype, enhanced } \\
\text { adherence to human pneumocytes and enhanced virulence in a } \\
\text { nematode infection assay. }\end{array}$ & {$[72,73]$} \\
\hline
\end{tabular}

\section{5. $\operatorname{Pmr} A B$}

In response to the increasing drug resistance of $A$. baumannii, including resistance to fluoroquinolones and carbapenems, the cationic peptide antibiotic colistin (polymyxin E) has become a last line of defence to treat infections with MDR A. baumannii strains [74,75]. However, colistin-resistant strains have emerged and one mechanism of resistance is mediated by mutations in the TCS encoded by pmrAB (polymyxin resistance) [76,77]. Indeed, PmrAB has been implicated in polymyxin B and colistin resistance in several other species, such as Pseudomonas aeruginosa, Klebsiella pneumoniae and Salmonella enterica [78-81]. In addition, the pmrAB TCS has been shown to regulate genes involved in lipopolysaccharide modification [80,82]. Colistin resistance in $A$. baumannii is conferred by mutations in $p m r A B$ that lead to overexpression of the response regulator PmrA and/or the sensor kinase PmrB, which suggests that differential expression of members of the $p m r A B$ regulon are responsible for the 
resistant phenotype. However, the complete regulon controlled by PmrAB in A. baumannii has not been investigated in detail.

Modifications of lipopolysaccharides (LPS) in the cell envelope are recognized mechanisms that cause polymyxin resistance. For instance, in Salmonella, addition of 4-amino-4-deoxy-L-arabinose or phosphoethanolamine to lipid A reduces the overall negative surface charge of the bacterial cell and thereby decreases electrostatic interactions with cationic peptides [83-87]. As well, changes in PmrB levels in colistin-resistant A. baumannii strains led to modification of lipid A with phosphoethanolamine $[65,88]$. Conversely, complete loss of LPS increases colistin resistance, but it is yet to be determined whether pmrAB is directly involved in this resistance [89]. Slightly acidic $\mathrm{pH}\left(\mathrm{pH}\right.$ 5.5), ferric iron $\left(\mathrm{Fe}^{3+}\right)$ or low magnesium levels could be the signals sensed by the sensor kinase PmrB, as these environmental conditions increase the MIC for colistin [76,88,90]. Acquiring colistin resistance through mutations in $p m r A B$ can lead to decreased bacterial fitness in in vitro growth experiments and in in vivo infection models [91-94]. For example, colistin-resistant clinical isolates showed impaired virulence in a rat model of pneumonia [95] and in intraperitoneally infected mice that were attributed to mutations in PmrAB [91]. In addition to conferring resistance to polymyxins, PmrAB might control the expression of a set of virulence factors or the changes of lipid A modification could directly account for the altered virulence phenotypes [88].

\section{Regulation of Iron and Zinc Acquisition}

The acquisition of metals, such as iron, zinc or manganese, is essential for all living organisms, because they are key to many important physiological processes. Depleting bacterial pathogens of essential metals is a host strategy to limit pathogen expansion-a strategy termed nutritional immunity [96-98]. The host expresses a set of proteins, such as haemoglobin, transferrin, lactoferrin or calprotectin that sequester iron, zinc and manganese making them less available for an invading pathogen. To subvert the host defence mechanisms, bacterial pathogens have evolved strategies to counter metal limitation by expressing efficient metal uptake systems and secrete molecules that bind metals in the environment and that may subsequently be taken up again. In A. baumannii, the regulation of the systems controlling iron and zinc acquisition have been studied and are reviewed below.

\subsection{Fur-the Ferric Uptake Regulator}

Iron is required for many cellular processes, for instance for DNA precursor synthesis or as cofactors in redox enzymes. To compete for iron with the host, bacteria have evolved intricate iron acquisition mechanisms. One mechanism to secure free iron is to secrete iron-chelating molecules (siderophores) which may later be taken up again from the environment or to scavenge iron bound to host transferrin and lactoferrin [99]. In bacteria, siderophore-encoding genes are often located in gene clusters. In A. baumannii, genomic comparisons have identified five siderophore gene clusters, however, A. baumannii isolates may possess different siderophore repertoires [66,100]. One well-characterized siderophore is termed acinetobactin $[99,101]$, which is structurally and functionally related to anguibactin from Vibrio anguillarum [102]. Acinetobactin-facilitated iron acquisition has been reported to be an important virulence factor in several A. baumannii infection models [103]. Upon inactivation of the acinetobactin-mediated iron uptake and utilization system, reduced apoptosis in A. baumannii infected alveolar epithelial cells A549 was reported and decreased virulence in Galleria mellonella larvae infections and a mouse sepsis model was observed [103]. In many Gram-negative bacteria including A. baumannii, iron acquisition-related genes are controlled by the ferric uptake regulator (Fur). The Fur protein is a transcriptional repressor that binds a $19 \mathrm{bp}$ AT-rich consensus sequence, called the "Fur box" when containing ferrous iron $\left(\mathrm{Fe}^{2+}\right)$ [66], and the Fur amino acid sequence in A. baumannii is $63 \%$ identical with the well-studied Fur protein in E. coli [104]. In response to iron limitation in vitro, 1207 A. baumannii ATCC17978 genes showed differential gene expression [66]. The siderophore clusters 1 and 2 and the acinetobactin cluster were strongly upregulated clusters and they possess candidate Fur-binding sites suggesting that Fur is directly involved in expression of 
siderophores. A second Fur-like protein (ABEYE1889) has been discovered in A. baumannii, however, it appears to be restricted to the A. baumannii AYE strain so far [66]. Functional characterization of ABEYE1889 is lacking, however, it might add complexity to the control of iron homeostasis. Fur has also been suggested to be involved in regulating the tonB-exbB-exbD system which is energizing transport processes across the outer membrane, for example of iron-siderophore complexes $[105,106]$. In $A$. baumannii ATCC19606, three ton $B$ genes have been identified and only the expression of ton $B_{3}$ responds to iron levels and is predicted to be Fur-regulated. The tonB-exbB-exbD might play a role in A. baumannii infections, as TonB proteins were required for full virulence in Galleria mellonella larvae infections [105].

\subsection{Zur-the Zinc Uptake Regulator}

In bacteria, zinc is required for the action of metalloproteins, such as metalloproteases [107]. In response to zinc limitation, $A$. baumannii upregulates an inner membrane $\mathrm{ABC}$ transporter encoded by the $z n u A B C$ genes to increase zinc uptake [67]. The regulation of zinc-associated genes is controlled by Zur (zinc uptake regulator), a zinc-binding regulatory protein and a member of the Fur protein family $[67,68]$. Like Fur, Zur functions as a transcriptional repressor binding to DNA at 19 bp consensus sequence in a zinc-dependent manner. De-repression of Zur-controlled genes occurs in zinc-depleted conditions, when the Zur apoprotein can no longer bind to DNA. In an A. baumannii transcriptomic study, deletion of zur resulted in differential expression of 144 genes, however, it is unclear how many are directly regulated by Zur. Among the differentially expressed genes were 11 (seven upregulated and four downregulated in the zur mutant strain) transcription factors suggesting significant cross-talk with other regulatory systems. Zinc acquisition is crucial for $A$. baumannii virulence. In a mouse pneumonia model, Zur was shown to be required for dissemination to the liver and this effect was abolished in calprotectin-deficient mice $[67,68]$.

Considered together, this illustrates the importance of precise regulation of metal acquisition systems and homeostasis for A. baumannii during infection. Thus, antimicrobials targeting these systems might prove to be particularly promising. For instance, the iron mimetic gallium nitrate $\left(\mathrm{Ga}\left(\mathrm{NO}_{3}\right)\right)$ inhibited growth of 58 A. baumannii strains in defined medium and in human serum and increased the survival rate of A. baumannii-infected Galleria mellonella larvae [108]. In addition, gallium nitrate dispersed A. baumannii biofilms produced in complement-free human serum [109]. Gallium competes with iron for bacterial iron acquisition systems and iron-binding proteins and may inhibit their function, because unlike $\mathrm{Fe}^{3+}, \mathrm{Ga}^{3+}$ cannot be reduced under physiological conditions [110,111]. Thus, gallium-based compounds may be included in effective antibacterial treatment strategies.

\section{Biofilm Formation and Quorum Sensing}

Biofilm formation by pathogenic bacteria is a challenge in healthcare because biofilms make bacteria more resistant to antibiotics, reduce the effectiveness of decontamination efforts, and increase persistence of bacteria on indwelling devices. Multiple regulatory pathways have been implicated in biofilm formation by $A$. baumannii, including the surprising finding that biofilm formation on polystyrene surfaces requires BfmR (described above), but not BfmS [54]. Several studies have linked biofilm formation by A. baumannii to quorum sensing. A. baumannii encodes $a b a I$ and $a b a R$, homologs of Vibrio's archetypal quorum sensing genes luxI and luxR, respectively [112,113]. The enzyme AbaI produces $\mathrm{N}$-acyl-homoserine lactone (AHL), a diffusible molecule that functions as an autoinducer by binding the AHL-responsive transcription factor AbaR [112]. Deleting abaI reduces biofilm formation in A. baumannii [69,112]. Surveys of clinical isolates indicate that about half can form biofilms in laboratory conditions, yet only a subset of biofilm-forming strains produce AHL [69,70]. Bacteria transition from free-living to biofilm physiology by producing adherent proteins and extracellular matrices that reinforce biofilm structures; for example, in the well-characterized model Pseudomonas, genes for biofilm formation are regulated by quorum sensing systems [114]. Thus, it is reasonable to hypothesize that AbaR activates biofilm gene expression in A. baumannii when AHLs rise to 
autoinducing concentrations. Curiously, some A. baumannii strains only encode an orphan abaI that appears to lack the cognate response regulator $a b a R$ [70]. This is counter to genome-wide analyses which indicate that luxR homologs usually outnumber luxI homologs [115], and that some species have a luxR homolog for sensing AHL signals but lack luxI and so do not contribute to signalling [116]. Could the unusual A. baumannii strains represent a special case of organisms that generate AHLs but do not sense them? In other words, might these A. baumannii strains generate AHLs for interspecies signalling to manipulate gene expression in neighbouring strains? Alternatively, in the absence of AbaR, AbaI may cross-talk with other quorum sensing systems in the same cell.

\section{Other Regulatory Proteins}

\subsection{AtfA}

The acidic transcription factor A (AtfA) in Acinetobacter spp. is a small protein (67-68 amino acids) that was first functionally described in A. baylyi ADP1 [71]. The gene has been unfortunately termed atf $A$, which is a name shared with the wax ester synthase/acyl-CoA:diacylglycerol acetyltransferase enzyme in A. baylyi ADP1 $[117,118]$. Deletion of atfA transcription factor resulted in gene expression changes of over 500 genes including several virulence-associated traits. Massive phenotypic changes were observed in atfA deletions in A. baylyi ADP1 and A. baumannii ATCC19606, including cell enlargement, loss of biofilm formation, reduced twitching motility and increased susceptibility to antibiotics and ethanol. Differences in response to ethanol might alter the expression of ethanol-induced virulence factors, such as phospholipase C [119]. Mechanistically, AtfA does not seem to be a classical transcription factor, but was shown to bind directly to RNA polymerase in a 1:1 ratio. This displaced DNA from RNA polymerase core complexes, but did not displace DNA from the holoenzyme containing a sigma factor [71]. The location of atf $A$ adjacent to the gene encoding the major sigma factor 70 could be significant for the co-regulation of this transcription factor with core transcriptional machinery. Thus, the extent of gene expression and phenotypic changes and the mechanistic insight into AtfA action indicate that AtfA is a global regulator. AtfA is conserved in the gamma-proteobacteria Moraxella, Pseudomonas, Legionella, Vibrio and Acinetobacter, but absent in Enterobacteriaceae [71].

\subsection{Nucleoid-Associated Protein H-NS}

Nucleoid-associated proteins and DNA supercoiling shape the bacterial nucleoid $[120,121]$. By virtue of their high abundance, binding across the bacterial chromosome, and the ability to constrain regions of DNA supercoiling, nucleoid-associated proteins affect the expression of many hundreds of genes in model organisms like E. coli and Salmonella [122]. Acinetobacter sp. encode an H-NS homolog that can complement an E. coli hns deletion mutant [72]. Deletion of the A. baumannii ATCC 17978 hns homolog (A1S_0268) caused a hyper-motile phenotype along with enhanced adherence to human pneumocytes and enhanced virulence in a nematode infection assay [73]. Ninety-one genes were upregulated in the hns mutant, including the genes encoding the virulence-associated adhesin ata (A1S_1032), a type-VI secretion system (A1S_1292-1311), and genes for type I pili. The most highly upregulated genes had AT-rich promoter regions, consistent with H-NS affinity for AT-rich DNA in the well-studied E. coli and Salmonella systems. A role for A. baumannii H-NS in xenogeneic silencing was reported as several genomic islands were found to be repressed by H-NS [73]. To our knowledge, gene regulatory effects of DNA supercoiling have not been studied in Acinetobacter.

\section{Global Studies Identifying Important Regulators}

Random global mutagenesis studies in bacteria have been instrumental to studying gene function. About a decade ago, classical genetic screenings using mobile genetic elements, such as transposons, have been paired with next-generation sequencing to allow high throughput identification and quantification of transposon insertions to assess the contribution of transposon-disrupted genes to bacterial fitness $[123,124]$. Among many other studies, transposon-insertion sequencing allowed 
the identification of Salmonella genes involved in colonization of farm animals [125], revealed novel genotype-phenotype relationships in Streptococcus pneumoniae [126] and detected essential genes in Rhizobiaceae [127]. Transposon-insertion sequencing in a A. baumannii ATCC17978 pneumonia model identified seven regulatory proteins that contribute to lung persistence (Table 2, [128]). Among them are the aforementioned response regulators GacA and BfmR, as well as the BfmS sensor kinase. Integration host factor (IHF), a homolog of the E. coli nucleoid-associated protein IHF, was shown to be required for virulence, however, H-NS was not. Acinetobacter junii and E. coli IHF bind similar DNA sites and both can repress transcription [129], but little else is known about Acinetobacter IHF function. Other predicted regulators required for persistence in the mouse lung are two LysR-type regulators (A1S_2122, A1S_2537, Table 2) and the putative high affinity phosphate uptake regulator phoU (Table 2), none of which have been studied in detail. Prediction of gene function suggested involvement of A1S_2122 in methionine synthesis [128]. The gene encoding A1S_2537 lies downstream of a number of genes predicted to mediate sulfate transport. Thus, both regulators might be involved in metabolism of sulfur-containing molecules. More recently, Gebhardt et al. performed a transposon-screen in A. baumannii strain AB5075 showing that virulence and resistance genes appear to be co-regulated in response to antibiotic and environmental stress [130]. In the same study, 17 (putative) regulatory proteins were identified that were required for growth in Galleria mellonella larvae (Table 3), suggesting that strains possessing increased resistance to antibiotics might simultaneously possess improved virulence properties.

Table 2. Regulators required for persistence in the mouse lung (ATCC17978; [128]).

\begin{tabular}{|c|c|c|c|c|}
\hline \multirow{2}{*}{$\begin{array}{l}\text { Gene } \\
\text { Name }\end{array}$} & \multicolumn{3}{|c|}{ Gene Identifier } & \multirow{2}{*}{ Product } \\
\hline & ATCC17978 & ATCC17978-mff & AB5075-UW & \\
\hline$g a c A$ & A1S_0236 & ACX60_RS16900 & ABUW_RS17720 & Two-component response regulator \\
\hline phou & A1S_0256 & ACX60_RS16800 & ABUW_RS17620 & $\begin{array}{l}\text { High affinity phosphate uptake } \\
\text { transcriptional repressor }\end{array}$ \\
\hline$i h f A$ & A1S_0603 & ACX60_RS15110 & ABUW_RS15930 & Integration host factor subunit alpha \\
\hline$b f m R$ & A1S_0748 & ACX60_RS14635 & ABUW_RS15450 & Two-component response regulator \\
\hline$b f m S$ & A1S_0749 & ACX60_RS14630 & ABUW_RS15445 & Two-component sensor histidine kinase \\
\hline- & A1S_2122 & ACX60_RS06950 & ABUW_RS07810 & LysR family transcriptional regulator \\
\hline- & A1S_2537 & ACX60_RS04880 & ABUW_RS04985 & LysR family transcriptional regulator \\
\hline
\end{tabular}

Table 3. Regulators required for growth in Galleria mellonella (AB5075; [130]).

\begin{tabular}{ccccc}
\hline \multirow{2}{*}{$\begin{array}{c}\text { Gene } \\
\text { Name }\end{array}$} & \multicolumn{3}{c}{ Gene Identifier } & \\
\cline { 2 - 4 } & ATCC17978 & ATCC17978-mff & AB5075-UW & Product \\
\hline- & A1S_2082 & ACX60_RS11775 & ABUW_RS08030 & TetR family transcriptional regulator \\
- & A1S_2064 & ACX60_RS07270 & ABUW_RS08145 & LysR family transcriptional regulator \\
- & A1S_2042 & ACX60_RS07365 & ABUW_RS08240 & TetR family transcriptional regulator \\
- & A1S_1958 & ACX60_RS08015 & ABUW_RS08550 & AsnC family transcriptional regulator \\
- & A1S_1948 & ACX60_RS08070 & ABUW_RS08610 & MarR family transcriptional regulator \\
- & A1S_1874 & ACX60_RS08460 & ABUW_RS09000 & LysR family transcriptional regulator \\
- & not present & not present & ABUW_RS09560 & LysR family transcriptional regulator \\
- & not present & not present & ABUW_RS10070 & Fur family transcriptional regulator \\
alkR & A1S_1640 & ACX60_RS09755 & ABUW_RS10675 & AraC family transcriptional regulator \\
- & A1S_1578 & ACX60_RS10205 & ABUW_RS10870 & AraC family transcriptional regulator \\
arsR & A1S_1453 & ACX60_RS10865 & ABUW_RS11530 & ArsR family transcriptional regulator \\
- & A1S_1350 & ACX60_RS11395 & ABUW_RS12250 & TetR family transcriptional regulator \\
- & A1S_1330 & ACX60_RS11505 & ABUW_RS12365 & AraC family transcriptional regulator \\
soxR & A1S_1320 & ACX60_RS11550 & ABUW_RS12410 & Redox-sensitive transcriptional activator \\
- & A1S_0768 & ACX60_RS14535 & ABUW_RS15350 & LysR family transcriptional regulator \\
bfmS & A1S_0749 & ACX60_RS14630 & ABUW_RS15445 & Two-component sensor histidine kinase \\
- & A1S_0621 & ACX60_RS15010 & ABUW_RS15830 & Putative two-component response regulator \\
\hline
\end{tabular}


The large number of important, yet functionally uncharacterized virulence gene regulators (Tables 2 and 3) highlight the need to study their regulons to obtain a more complete picture of the regulatory networks governing virulence gene expression. These approaches need to be extended to study antibiotic resistance genes and their regulation to reveal novel potential target for drug intervention. Novel global genomic approaches, such as CRISPR interference (CRISPRi), promise to accelerate the understanding of gene function and regulation [124,131].

\section{Do Small Regulatory RNAs Have a Role in A. baumannii Virulence or Antibiotic Resistance?}

Small RNAs (sRNAs) are now fully established as a class of gene regulators of various cellular processes in bacteria [132-135]. Best understood are expression patterns and regulatory mechanisms employed by small non-coding RNAs in Enterobacteriaceae such as E. coli and Salmonella [136-140]. So far, we lack information as to whether sRNA-mediated regulation in A. baumannii is analogous to these well-studied systems. Bioinformatic analysis of the A. baumannii ATCC17978 genome identified 31 putative small RNA candidates, of which three were confirmed by Northern blotting using strain ATCC15308 [141]. In the multidrug resistant $A$. baumannii strain AB5075, 78 small RNAs were identified using RNA-sequencing [142]. However, we lack insight as to whether these sRNA candidates possess any physiological function or how they might function mechanistically.

In Enterobacteriaceae, one function of the RNA-binding protein Hfq is to facilitate the interaction of sRNA and their cognate mRNA targets [143]. Yet in Acinetobacter's closer relative, Pseudomonas aeruginosa, the role of Hfq in sRNA-mediated regulation is less clear and does not seem to follow the same model as in Enterobacteriaceae [144,145]. In Acinetobacter spp., Hfq has only been studied in the avirulent $A$. baylyi. Hfq possesses an unusually long, glycine-rich C-terminus, which is a unique feature of Acinetobacter spp. Hfq. This may impact how and where RNAs bind to Hfq, as well as how Hfq interacts with other cellular players [146]. In other bacterial pathogens, deletions in RNA binding proteins such as Hfq or CsrA often results in avirulent phenotypes [147-150], however, the role of Hfq in A. baumannii virulence or antibiotic resistance remains unknown. Only the sRNA Aar has been studied as a regulatory RNA in A. baylyi. Aar, which is conserved in A. baumannii [142,151], was suggested to play a role in amino acid metabolism of $A$. baylyi, but mechanistic details remain unknown [151]. Several Hfq-dependent sRNAs have been described to control iron homeostasis in other Gram-negative bacteria [152,153] and there might be a connection of sRNA-mediated gene regulation and iron homeostasis in A. baumannii, because a proteomic study showed that A. baumannii Hfq protein levels decreased in iron-limiting conditions [154]. Moreover, Hfq protein and Hfq-dependent sRNAs have been identified to play a role in antibiotic resistance, as small RNAs control the expression of many cellular targets of antibiotic action [155-157]. In Enterobacteriaceae, outer membrane homeostasis of major porins OmpA, OmpC, OmpD and OmpF is controlled by the concerted action of several small RNAs [158-163]. In addition, the outer membrane component of the RND superfamily multidrug transporter TolC is regulated by the sRNA SdsR in E. coli [164]. Considering the prominent role of OmpA in A. baumannii virulence and drug resistance [165-167], it will be interesting to investigate whether a similar sRNA-mediated control of $A$. baumannii OmpA and other outer membrane proteins exists.

Considered together, it will be important to elucidate the regulons and regulatory mechanisms of sRNA along with identification and characterisation of RNA binding proteins in Acinetobacter-especially during infection and upon exposure to antibiotics.

\section{Conclusions and Outlook}

Bacterial pathogens must adapt quickly to changing environments, for example, during host entry or in harsh environmental conditions, and modulate their gene expression programs accordingly. This is achieved by multiple regulatory systems that govern correct spatiotemporal gene expression. In the bacterial pathogen A. baumannii, an increasing number of virulence genes have been identified over the last few years, however, their gene regulation remains largely unknown. So far, very few 
regulons have been defined and we lack data for all A. baumannii transcription factors whether regulatory effects are direct or indirect. This highlights the need to use and combine global approaches such as DNA binding studies using chromatin-immunoprecipitation (ChIP) sequencing, transposon-insertion sequencing, CRISPR interference and RNA-sequencing to define direct and indirect effects of regulatory proteins in A. baumannii and to identify regulators that control virulence gene expression and antibiotic resistance. In addition, the extent and mechanisms of RNA-mediated gene regulation remain completely unknown. To improve the ability to study gene regulation in detail, the range of basic molecular tools, such as reporter plasmids, needs to be expanded, however, this can be hampered by the multidrug resistant genotypes of clinical isolates and the lack of detailed knowledge about restriction modification systems in A. baumannii. Moreover, to make generalizing statements about $A$. baumannii virulence and antibiotic resistance as well as their genetic regulation is complicated by the significant strain-to-strain differences. Thus, we require multiple efforts to understand how genes are regulated in this important opportunistic pathogen that could inform the development of knowledge-based interventions.

Acknowledgments: Acinetobacter research in the Cameron lab is supported by a Natural Sciences and Engineering Research Council of Canada Discovery grant (RGPIN-435784-2013) and in the Kröger lab by Trinity College Dublin.

Conflicts of Interest: The authors declare no conflict of interest. The funding sponsors had no role in the writing of the manuscript.

\section{References}

1. Brown, E.D.; Wright, G.D. Antibacterial drug discovery in the resistance era. Nature 2016, 529, $336-343$. [CrossRef] [PubMed]

2. Tommasi, R.; Brown, D.G.; Walkup, G.K.; Manchester, J.I.; Miller, A.A. ESKAPEing the labyrinth of antibacterial discovery. Nat. Rev. Drug Discov. 2015, 14, 529-542. [CrossRef] [PubMed]

3. Boucher, H.W.; Talbot, G.H.; Bradley, J.S.; Edwards, J.E.; Gilbert, D.; Rice, L.B.; Scheld, M.; Spellberg, B.; Bartlett, J. Bad Bugs, No Drugs: No ESKAPE! An Update from the Infectious Diseases Society of America. Clin. Infect. Dis. 2009, 48, 1-12. [CrossRef] [PubMed]

4. Rice, L.B. Federal Funding for the Study of Antimicrobial Resistance in Nosocomial Pathogens: No ESKAPE. J. Infect. Dis. 2008, 197, 1079-1081. [CrossRef] [PubMed]

5. Spellberg, B.; Bonomo, R.A. The Deadly Impact of Extreme Drug Resistance in Acinetobacter baumannii. Crit. Care Med. 2014, 42, 1289-1291. [CrossRef] [PubMed]

6. Dijkshoorn, L.; Nemec, A.; Seifert, H. An increasing threat in hospitals: Multidrug-resistant Acinetobacter baumannii. Nat. Rev. Microbiol. 2007, 5, 939-951. [CrossRef] [PubMed]

7. Antunes, L.C.S.; Visca, P.; Towner, K.J. Acinetobacter baumannii: Evolution of a global pathogen. Pathog. Dis. 2014, 71, 292-301. [CrossRef] [PubMed]

8. Roca, I.; Espinal, P.; Vila-Farrés, X.; Vila, J. The Acinetobacter baumannii Oxymoron: Commensal Hospital Dweller Turned Pan-Drug-Resistant Menace. Front. Microbiol. 2012, 3, 148. [CrossRef] [PubMed]

9. Peleg, A.Y.; Seifert, H.; Paterson, D.L. Acinetobacter baumannii: Emergence of a Successful Pathogen. Clin. Microbiol. Rev. 2008, 21, 538-582. [CrossRef] [PubMed]

10. McConnell, M.J.; Actis, L.; Pachón, J. Acinetobacter baumannii: Human infections, factors contributing to pathogenesis and animal models. FEMS Microbiol. Rev. 2012, 37, 130-155. [CrossRef] [PubMed]

11. Espinal, P.; Roca, I.; Vila, J. Clinical impact and molecular basis of antimicrobial resistance in non-baumannii Acinetobacter. Future Microbiol. 2011, 6, 495-511. [CrossRef] [PubMed]

12. Falagas, M.E.; Karveli, E.A.; Kelesidis, I.; Kelesidis, T. Community-acquired Acinetobacter infections. Eur. J. Clin. Microbiol. Infect. Dis. 2007, 26, 857-868. [CrossRef] [PubMed]

13. Dexter, C.; Murray, G.L.; Paulsen, I.T.; Peleg, A.Y. Community-acquired Acinetobacter baumannii: Clinical characteristics, epidemiology and pathogenesis. Expert Rev. Anti Infect. Ther. 2015, 13, 567-573. [CrossRef] [PubMed]

14. Jacobs, A.C.; Thompson, M.G.; Black, C.C.; Kessler, J.L.; Clark, L.P.; McQueary, C.N.; Gancz, H.Y.; Corey, B.W.; Moon, J.K.; Si, Y.; et al. AB5075, a Highly Virulent Isolate of Acinetobacter baumannii, as a Model Strain for the Evaluation of Pathogenesis and Antimicrobial Treatments. mBio 2014, 5, e01076-14. [CrossRef] [PubMed] 
15. Joly-Guillou, M.-L. Clinical impact and pathogenicity of Acinetobacter. Clin. Microbiol. Infect. 2005, 11, 868-873. [CrossRef] [PubMed]

16. Lemos, E.V.; de la Hoz, F.P.; Einarson, T.R.; McGhan, W.F.; Quevedo, E.; Castañeda, C.; Kawai, K. Carbapenem resistance and mortality in patients with Acinetobacter baumannii infection: Systematic review and meta-analysis. Clin. Microbiol. Infect. 2014, 20, 416-423. [CrossRef] [PubMed]

17. Spellberg, B.; Rex, J.H. The value of single-pathogen antibacterial agents. Nat. Rev. Drug Discov. 2013, $12,963$. [CrossRef] [PubMed]

18. Göttig, S.; Gruber, T.M.; Higgins, P.G.; Wachsmuth, M.; Seifert, H.; Kempf, V.A.J. Detection of pan drug-resistant Acinetobacter baumannii in Germany. J. Antimicrob. Chemother. 2014, 69, 2578-2579.

19. Chen, Z.; Qiu, S.; Wang, Y.; Wang, Y.; Liu, S.; Wang, Z.; Du, X.; Wang, L.; Guo, J.; Wang, Z.; et al. Coexistence of blaNDM-1 with the Prevalent blaOXA23 and blaIMP in Pan-drug Resistant Acinetobacter baumannii Isolates in China. Clin. Infect. Dis. 2011, 52, 692-693. [CrossRef] [PubMed]

20. Valencia, R.; Arroyo, L.A.; Conde, M.; Aldana, J.M.; Torres, M.-J.; Fernández-Cuenca, F.; Garnacho-Montero, J.; Cisneros, J.M.; Ortiz, C.; Pachón, J.; et al. Nosocomial Outbreak of Infection With Pan-Drug-Resistant Acinetobacter baumannii in a Tertiary Care University Hospital. Infect. Control Hosp. Epidemiol. 2009, 30, 257-263. [CrossRef] [PubMed]

21. Wang, S.H.; Sheng, W.H.; Chang, Y.Y.; Wang, L.H.; Lin, H.C.; Chen, M.L.; Pan, H.J.; Ko, W.J.; Chang, S.C.; Lin, F.Y. Healthcare-associated outbreak due to pan-drug resistant Acinetobacter baumannii in a surgical intensive care unit. J. Hosp. Infect. 2003, 53, 97-102. [CrossRef] [PubMed]

22. Taherikalani, M.; Etemadi, G.; Geliani, K.N.; Fatollahzadeh, B.; Soroush, S.; Feizabadi, M.M. Emergence of multi and pan-drug resistance Acinetobacter baumannii carrying blaOXA-type -carbapenemase genes among burn patients in Tehran, Iran. Saudi Med. J. 2008, 29, 623-624. [PubMed]

23. Vila, J.; Pachón, J. Acinetobacter baumannii resistant to everything: What should we do? Clin. Microbiol. Infect. 2011, 17, 955-956. [CrossRef] [PubMed]

24. Weber, B.S.; Harding, C.M.; Feldman, M.F. Pathogenic Acinetobacter: From the Cell Surface to Infinity and Beyond. J. Bacteriol. 2016, 198, 880-887. [CrossRef] [PubMed]

25. Groisman, E.A. Feedback Control of Two-Component Regulatory Systems. Annu. Rev. Microbiol. 2016, 70, 103-124. [CrossRef] [PubMed]

26. Choi, J.; Groisman, E.A. Acidic pH sensing in the bacterial cytoplasm is required for Salmonella virulence. Mol. Microbiol. 2016, 101, 1024-1038. [CrossRef] [PubMed]

27. Capra, E.J.; Laub, M.T. Evolution of Two-Component Signal Transduction Systems. Annu. Rev. Microbiol. 2012, 66, 325-347. [CrossRef] [PubMed]

28. Quinn, H.J.; Cameron, A.D.S.; Dorman, C.J. Bacterial Regulon Evolution: Distinct Responses and Roles for the Identical OmpR Proteins of Salmonella Typhimurium and Escherichia coli in the Acid Stress Response. PLoS Genet. 2014, 10, e1004215. [CrossRef] [PubMed]

29. Walthers, D.; Carroll, R.K.; Navarre, W.W.; Libby, S.J.; Fang, F.C.; Kenney, L.J. The response regulator SsrB activates expression of diverse Salmonella pathogenicity island 2 promoters and counters silencing by the nucleoid-associated protein H-NS. Mol. Microbiol. 2007, 65, 477-493. [CrossRef] [PubMed]

30. Desai, S.K.; Winardhi, R.S.; Periasamy, S.; Dykas, M.M.; Jie, Y.; Kenney, L.J. The horizontally-acquired response regulator SsrB drives a Salmonella lifestyle switch by relieving biofilm silencing. eLife 2016, 5, e10747. [CrossRef] [PubMed]

31. Gallagher, L.A.; Ramage, E.; Weiss, E.J.; Radey, M.; Hayden, H.S.; Held, K.G.; Huse, H.K.; Zurawski, D.V.; Brittnacher, M.J.; Manoil, C. Resources for Genetic and Genomic Analysis of Emerging Pathogen Acinetobacter baumannii. J. Bacteriol. 2015, 197, 2027-2035. [CrossRef] [PubMed]

32. Ashby, M.K. Survey of the number of two-component response regulator genes in the complete and annotated genome sequences of prokaryotes. FEMS Microbiol. Lett. 2004, 231, 277-281. [CrossRef]

33. Brittnacher, M.J.; Fong, C.; Hayden, H.S.; Jacobs, M.A.; Radey, M.; Rohmer, L. PGAT: A multistrain analysis resource for microbial genomes. Bioinformatics 2011, 27, 2429-2430. [CrossRef] [PubMed]

34. Magnet, S.; Courvalin, P.; Lambert, T. Resistance-Nodulation-Cell Division-Type Efflux Pump Involved in Aminoglycoside Resistance in Acinetobacter baumannii Strain BM4454. Antimicrob. Agents Chemother. 2001, 45, 3375-3380. [CrossRef] [PubMed] 
35. Marchand, I.; Damier-Piolle, L.; Courvalin, P.; Lambert, T. Expression of the RND-Type Efflux Pump AdeABC in Acinetobacter baumannii Is Regulated by the AdeRS Two-Component System. Antimicrob. Agents Chemother. 2004, 48, 3298-3304. [CrossRef] [PubMed]

36. Nemec, A.; Maixnerová, M.; van der Reijden, T.J.K.; van den Broek, P.J.; Dijkshoorn, L. Relationship between the AdeABC efflux system gene content, netilmicin susceptibility and multidrug resistance in a genotypically diverse collection of Acinetobacter baumannii strains. J. Antimicrob. Chemother. 2007, 60, 483-489. [CrossRef] [PubMed]

37. Ruzin, A.; Keeney, D.; Bradford, P.A. AdeABC multidrug efflux pump is associated with decreased susceptibility to tigecycline in Acinetobacter calcoaceticus-Acinetobacter baumannii complex. J. Antimicrob. Chemother. 2007, 59, 1001-1004. [CrossRef] [PubMed]

38. Coyne, S.; Guigon, G.; Courvalin, P.; Périchon, B. Screening and Quantification of the Expression of Antibiotic Resistance Genes in Acinetobacter baumannii with a Microarray. Antimicrob. Agents Chemother. 2010, 54, 333-340. [CrossRef] [PubMed]

39. Yoon, E.-J.; Courvalin, P.; Grillot-Courvalin, C. RND-Type Efflux Pumps in Multidrug-Resistant Clinical Isolates of Acinetobacter baumannii: Major Role for AdeABC Overexpression and AdeRS Mutations. Antimicrob. Agents Chemother. 2013, 57, 2989-2995. [CrossRef] [PubMed]

40. Hornsey, M.; Ellington, M.J.; Doumith, M.; Thomas, C.P.; Gordon, N.C.; Wareham, D.W.; Quinn, J.; Lolans, K.; Livermore, D.M.; Woodford, N. AdeABC-mediated efflux and tigecycline MICs for epidemic clones of Acinetobacter baumannii. J. Antimicrob. Chemother. 2010, 65, 1589-1593. [CrossRef] [PubMed]

41. Nowak, J.; Schneiders, T.; Seifert, H.; Higgins, P.G. The Asp20-to-Asn Substitution in the Response Regulator AdeR Leads to Enhanced Efflux Activity of AdeB in Acinetobacter baumannii. Antimicrob. Agents Chemother. 2016, 60, 1085-1090. [CrossRef] [PubMed]

42. Montaña, S.; Vilacoba, E.; Traglia, G.M.; Almuzara, M.; Pennini, M.; Fernández, A.; Sucari, A.; Centrón, D.; Ramírez, M.S. Genetic Variability of AdeRS Two-Component System Associated with Tigecycline Resistance in XDR-Acinetobacter baumannii Isolates. Curr. Microbiol. 2015, 71, 76-82. [CrossRef] [PubMed]

43. Sun, J.-R.; Chan, M.-C.; Chang, T.-Y.; Wang, W.-Y.; Chiueh, T.-S. Overexpression of the adeB Gene in Clinical Isolates of Tigecycline-Nonsusceptible Acinetobacter baumannii without Insertion Mutations in adeRS. Antimicrob. Agents Chemother. 2010, 54, 4934-4938. [CrossRef] [PubMed]

44. Yoon, E.-J.; Balloy, V.; Fiette, L.; Chignard, M.; Courvalin, P.; Grillot-Courvalin, C. Contribution of the Ade Resistance-Nodulation-Cell Division-Type Efflux Pumps to Fitness and Pathogenesis of Acinetobacter baumannii. mBio 2016, 7, e00697-16. [CrossRef] [PubMed]

45. Higgins, P.G.; Schneiders, T.; Hamprecht, A.; Seifert, H. In Vivo Selection of a Missense Mutation in adeR and Conversion of the Novel blaOXA-164 Gene into blaOXA-58 in Carbapenem-Resistant Acinetobacter baumannii Isolates from a Hospitalized Patient. Antimicrob. Agents Chemother. 2010, 54, 5021-5027. [CrossRef] [PubMed]

46. Coyne, S.; Courvalin, P.; Périchon, B. Efflux-Mediated Antibiotic Resistance in Acinetobacter spp. Antimicrob. Agents Chemother. 2011, 55, 947-953. [CrossRef] [PubMed]

47. Richmond, G.E.; Evans, L.P.; Anderson, M.J.; Wand, M.E.; Bonney, L.C.; Ivens, A.; Chua, K.L.; Webber, M.A.; Sutton, J.M.; Peterson, M.L.; et al. The Acinetobacter baumannii Two-Component System AdeRS Regulates Genes Required for Multidrug Efflux, Biofilm Formation, and Virulence in a Strain-Specific Manner. mBio 2016, 7, e00430-16. [PubMed]

48. Wright, M.S.; Iovleva, A.; Jacobs, M.R.; Bonomo, R.A.; Adams, M.D. Genome dynamics of multidrug-resistant Acinetobacter baumannii during infection and treatment. Genome Med. 2016, 8, 1-12. [CrossRef] [PubMed]

49. Wright, M.S.; Haft, D.H.; Harkins, D.M.; Perez, F.; Hujer, K.M.; Bajaksouzian, S.; Benard, M.F.; Jacobs, M.R.; Bonomo, R.A.; Adams, M.D. New Insights into Dissemination and Variation of the Health Care-Associated Pathogen Acinetobacter baumannii from Genomic Analysis. mBio 2014, 5, e00963-13. [CrossRef] [PubMed]

50. Lin, M.-F.; Lin, Y.-Y.; Yeh, H.-W.; Lan, C.-Y. Role of the BaeSR two-component system in the regulation of Acinetobacter baumannii adeAB genes and its correlation with tigecycline susceptibility. BMC Microbiol. 2014, 14, 119. [CrossRef] [PubMed]

51. Lin, M.-F.; Lin, Y.-Y.; Lan, C.-Y. The Role of the Two-Component System BaeSR in Disposing Chemicals through Regulating Transporter Systems in Acinetobacter baumannii. PLoS ONE 2015, 10, e0132843. [CrossRef] [PubMed]

52. Akiyama, H.; Fujii, K.; Yamasaki, O.; Oono, T.; Iwatsuki, K. Antibacterial action of several tannins against Staphylococcus aureus. J. Antimicrob. Chemother. 2001, 48, 487-491. [CrossRef] [PubMed] 
53. Chusri, S.; Villanueva, I.; Voravuthikunchai, S.P.; Davies, J. Enhancing antibiotic activity: A strategy to control Acinetobacter infections. J. Antimicrob. Chemother. 2009, 64, 1203-1211. [CrossRef] [PubMed]

54. Tomaras, A.P.; Flagler, M.J.; Dorsey, C.W.; Gaddy, J.A.; Actis, L.A. Characterization of a two-component regulatory system from Acinetobacter baumannii that controls biofilm formation and cellular morphology. Microbiology 2008, 154, 3398-3409. [CrossRef] [PubMed]

55. Gaddy, J.A.; Actis, L.A. Regulation of Acinetobacter baumannii biofilm formation. Future Microbiol. 2009, 4, 273-278. [CrossRef] [PubMed]

56. de Breij, A.; Gaddy, J.; van der Meer, J.; Koning, R.; Koster, A.; van den Broek, P.; Actis, L.; Nibbering, P.; Dijkshoorn, L. CsuA/BABCDE-dependent pili are not involved in the adherence of Acinetobacter baumannii ATCC19606T to human airway epithelial cells and their inflammatory response. Res. Microbiol. 2009, 160, 213-218. [CrossRef] [PubMed]

57. Liou, M.-L.; Soo, P.-C.; Ling, S.-R.; Kuo, H.-Y.; Tang, C.Y.; Chang, K.-C. The sensor kinase BfmS mediates virulence in Acinetobacter baumannii. J. Microbiol. Immunol. Infect. 2014, 47, 275-281. [CrossRef] [PubMed]

58. Russo, T.A.; Manohar, A.; Beanan, J.M.; Olson, R.; MacDonald, U.; Graham, J.; Umland, T.C. The Response Regulator BfmR Is a Potential Drug Target for Acinetobacter baumannii. mSphere 2016, 1, e00082-16. [CrossRef] [PubMed]

59. Geisinger, E.; Isberg, R.R. Antibiotic Modulation of Capsular Exopolysaccharide and Virulence in Acinetobacter baumannii. PLoS Pathog. 2015, 11, e1004691. [CrossRef] [PubMed]

60. Dorsey, C.W.; Tomaras, A.P.; Actis, L.A. Genetic and Phenotypic Analysis of Acinetobacter baumannii Insertion Derivatives Generated with a Transposome System. Appl. Environ. Microbiol. 2002, 68, 6353-6360. [CrossRef] [PubMed]

61. Peleg, A.Y.; Tampakakis, E.; Fuchs, B.B.; Eliopoulos, G.M.; Moellering, R.C.; Mylonakis, E. Prokaryote-eukaryote interactions identified by using Caenorhabditis elegans. Proc. Natl. Acad. Sci. USA 2008, 105, 14585-14590. [CrossRef] [PubMed]

62. Cerqueira, G.M.; Kostoulias, X.; Khoo, C.; Aibinu, I.; Qu, Y.; Traven, A.; Peleg, A.Y. A Global Virulence Regulator in Acinetobacter baumannii and Its Control of the Phenylacetic Acid Catabolic Pathway. J. Infect. Dis. 2014, 210, 46-55. [CrossRef] [PubMed]

63. Bhuiyan, M.S.; Ellett, F.; Murray, G.L.; Kostoulias, X.; Cerqueira, G.M.; Schulze, K.E.; Maifiah, M.H.M.; Li, J.; Creek, D.J.; Lieschke, G.J.; et al. Acinetobacter baumannii phenylacetic acid metabolism influences infection outcome through a direct effect on neutrophil chemotaxis. Proc. Natl. Acad. Sci. USA 2016, 113, 9599-9604. [CrossRef] [PubMed]

64. Teufel, R.; Mascaraque, V.; Ismail, W.; Voss, M.; Perera, J.; Eisenreich, W.; Haehnel, W.; Fuchs, G. Bacterial phenylalanine and phenylacetate catabolic pathway revealed. Proc. Natl. Acad. Sci. USA 2010, 107, 14390-14395. [CrossRef] [PubMed]

65. Arroyo, L.A.; Herrera, C.M.; Fernandez, L.; Hankins, J.V.; Trent, M.S.; Hancock, R.E.W. The pmrCAB Operon Mediates Polymyxin Resistance in Acinetobacter baumannii ATCC 17978 and Clinical Isolates through Phosphoethanolamine Modification of Lipid A. Antimicrob. Agents Chemother. 2011, 55, 3743-3751. [CrossRef] [PubMed]

66. Eijkelkamp, B.A.; Hassan, K.A.; Paulsen, I.T.; Brown, M.H. Investigation of the human pathogen Acinetobacter baumannii under iron limiting conditions. BMC Genomics 2011, 12, 126. [CrossRef] [PubMed]

67. Hood, M.I.; Mortensen, B.L.; Moore, J.L.; Zhang, Y.; Kehl-Fie, T.E.; Sugitani, N.; Chazin, W.J.; Caprioli, R.M.; Skaar, E.P. Identification of an Acinetobacter baumannii Zinc Acquisition System that Facilitates Resistance to Calprotectin-mediated Zinc Sequestration. PLoS Pathog. 2012, 8, e1003068. [CrossRef] [PubMed]

68. Mortensen, B.L.; Rathi, S.; Chazin, W.J.; Skaar, E.P. Acinetobacter baumannii Response to Host-Mediated Zinc Limitation Requires the Transcriptional Regulator Zur. J. Bacteriol. 2014, 196, 2616-2626. [CrossRef] [PubMed]

69. Anbazhagan, D.; Mansor, M.; Yan, G.O.S.; Yusof, M.Y.M.; Hassan, H.; Sekaran, S.D. Detection of Quorum Sensing Signal Molecules and Identification of an Autoinducer Synthase Gene among Biofilm Forming Clinical Isolates of Acinetobacter spp. PLoS ONE 2012, 7, e36696. [CrossRef] [PubMed]

70. Modarresi, F.; Azizi, O.; Shakibaie, M.R.; Motamedifar, M.; Mosadegh, E.; Mansouri, S. Iron limitation enhances acyl homoserine lactone (AHL) production and biofilm formation in clinical isolates of Acinetobacter baumannii. Virulence 2015, 6, 152-161. [CrossRef] [PubMed] 
71. Withers, R.; Doherty, G.P.; Jordan, M.; Yang, X.; Dixon, N.E.; Lewis, P.J. AtfA, a new factor in global regulation of transcription in Acinetobacter spp. Mol. Microbiol. 2014, 93, 1130-1143. [PubMed]

72. Tendeng, C.; Krin, E.; Soutourina, O.A.; Marin, A.; Danchin, A.; Bertin, P.N. A Novel H-NS-like Protein from an Antarctic Psychrophilic Bacterium Reveals a Crucial Role for the N-terminal Domain in Thermal Stability. J. Biol. Chem. 2003, 278, 18754-18760. [CrossRef] [PubMed]

73. Eijkelkamp, B.A.; Stroeher, U.H.; Hassan, K.A.; Elbourne, L.D.H.; Paulsen, I.T.; Brown, M.H. H-NS Plays a Role in Expression of Acinetobacter baumannii Virulence Features. Infect. Immun. 2013, 81, 2574-2583. [CrossRef] [PubMed]

74. Kaye, K.S.; Pogue, J.M.; Tran, T.B.; Nation, R.L.; Li, J. Agents of Last Resort: Polymyxin Resistance. Infect. Dis. Clin. N. Am. 2016, 30, 391-414. [CrossRef] [PubMed]

75. Trimble, M.J.; Mlynárčik, P.; Kolář, M.; Hancock, R.E.W. Polymyxin: Alternative Mechanisms of Action and Resistance. Cold Spring Harb. Perspect. Med. 2016, 6, a025288. [CrossRef] [PubMed]

76. Adams, M.D.; Nickel, G.C.; Bajaksouzian, S.; Lavender, H.; Murthy, A.R.; Jacobs, M.R.; Bonomo, R.A. Resistance to Colistin in Acinetobacter baumannii Associated with Mutations in the PmrAB Two-Component System. Antimicrob. Agents Chemother. 2009, 53, 3628-3634. [CrossRef] [PubMed]

77. Rolain, J.-M.; Diene, S.M.; Kempf, M.; Gimenez, G.; Robert, C.; Raoult, D. Real-Time Sequencing To Decipher the Molecular Mechanism of Resistance of a Clinical Pan-Drug-Resistant Acinetobacter baumannii Isolate from Marseille, France. Antimicrob. Agents Chemother. 2013, 57, 592-596. [CrossRef] [PubMed]

78. McPhee, J.B.; Lewenza, S.; Hancock, R.E.W. Cationic antimicrobial peptides activate a two-component regulatory system, PmrA-PmrB, that regulates resistance to polymyxin B and cationic antimicrobial peptides in Pseudomonas aeruginosa. Mol. Microbiol. 2003, 50, 205-217. [CrossRef] [PubMed]

79. Moskowitz, S.M.; Ernst, R.K.; Miller, S.I. PmrAB, a Two-Component Regulatory System of Pseudomonas aeruginosa That Modulates Resistance to Cationic Antimicrobial Peptides and Addition of Aminoarabinose to Lipid A. J. Bacteriol. 2004, 186, 575-579. [CrossRef] [PubMed]

80. Cheng, H.-Y.; Chen, Y.-F.; Peng, H.-L. Molecular characterization of the PhoPQ-PmrD-PmrAB mediated pathway regulating polymyxin B resistance in Klebsiella pneumoniae CG43. J. Biomed. Sci. 2010, 17, 60. [CrossRef] [PubMed]

81. Matamouros, S.; Miller, S.I.S. Typhimurium strategies to resist killing by cationic antimicrobial peptides. Biochim. Biophys. Acta BBA - Biomembr. 2015, 1848, 3021-3025. [CrossRef] [PubMed]

82. Marchal, K.; De Keersmaecker, S.; Monsieurs, P.; van Boxel, N.; Lemmens, K.; Thijs, G.; Vanderleyden, J.; De Moor, B. In silico identification and experimental validation of PmrAB targets in Salmonella typhimurium by regulatory motif detection. Genome Biol. 2004, 5, R9. [CrossRef] [PubMed]

83. Gunn, J.S.; Lim, K.B.; Krueger, J.; Kim, K.; Guo, L.; Hackett, M.; Miller, S.I. PmrA-PmrB-regulated genes necessary for 4-aminoarabinose lipid A modification and polymyxin resistance. Mol. Microbiol. 1998, 27, 1171-1182. [CrossRef] [PubMed]

84. Gunn, J.S.; Ryan, S.S.; Velkinburgh, J.C.V.; Ernst, R.K.; Miller, S.I. Genetic and Functional Analysis of a PmrA-PmrB-Regulated Locus Necessary for Lipopolysaccharide Modification, Antimicrobial Peptide Resistance, and Oral Virulence of Salmonella enterica Serovar Typhimurium. Infect. Immun. 2000, 68, 6139-6146. [CrossRef] [PubMed]

85. Lee, H.; Hsu, F.-F.; Turk, J.; Groisman, E.A. The PmrA-Regulated pmrC Gene Mediates Phosphoethanolamine Modification of Lipid A and Polymyxin Resistance in Salmonella enterica. J. Bacteriol. 2004, 186, 4124-4133. [CrossRef] [PubMed]

86. Olaitan, A.O.; Morand, S.; Rolain, J.-M. Mechanisms of polymyxin resistance: Acquired and intrinsic resistance in bacteria. Front. Microbiol. 2014, 5, 643. [CrossRef] [PubMed]

87. Chen, H.D.; Groisman, E.A. The Biology of the PmrA/PmrB Two-Component System: The Major Regulator of Lipopolysaccharide Modifications. Annu. Rev. Microbiol. 2013, 67, 83-112. [CrossRef] [PubMed]

88. Beceiro, A.; Llobet, E.; Aranda, J.; Bengoechea, J.A.; Doumith, M.; Hornsey, M.; Dhanji, H.; Chart, H.; Bou, G.; Livermore, D.M.; et al. Phosphoethanolamine Modification of Lipid A in Colistin-Resistant Variants of Acinetobacter baumannii Mediated by the pmrAB Two-Component Regulatory System. Antimicrob. Agents Chemother. 2011, 55, 3370-3379. [CrossRef] [PubMed]

89. Moffatt, J.H.; Harper, M.; Harrison, P.; Hale, J.D.F.; Vinogradov, E.; Seemann, T.; Henry, R.; Crane, B.; Michael, F.S.; Cox, A.D.; et al. Colistin Resistance in Acinetobacter baumannii Is Mediated by Complete Loss of Lipopolysaccharide Production. Antimicrob. Agents Chemother. 2010, 54, 4971-4977. [CrossRef] [PubMed] 
90. López-Rojas, R.; García-Quintanilla, M.; Labrador-Herrera, G.; Pachón, J.; McConnell, M.J. Impaired growth under iron-limiting conditions associated with the acquisition of colistin resistance in Acinetobacter baumannii. Int. J. Antimicrob. Agents 2016, 47, 473-477. [CrossRef] [PubMed]

91. López-Rojas, R.; Domínguez-Herrera, J.; McConnell, M.J.; Docobo-Peréz, F.; Smani, Y.; Fernández-Reyes, M.; Rivas, L.; Pachón, J. Impaired Virulence and In Vivo Fitness of Colistin-Resistant Acinetobacter baumannii. J. Infect. Dis. 2011, 203, 545-548. [CrossRef] [PubMed]

92. López-Rojas, R.; McConnell, M.J.; Jiménez-Mejías, M.E.; Domínguez-Herrera, J.; Fernández-Cuenca, F.; Pachón, J. Colistin Resistance in a Clinical Acinetobacter baumannii Strain Appearing after Colistin Treatment: Effect on Virulence and Bacterial Fitness. Antimicrob. Agents Chemother. 2013, 57, 4587-4589. [CrossRef] [PubMed]

93. Rolain, J.-M.; Roch, A.; Castanier, M.; Papazian, L.; Raoult, D. Acinetobacter baumannii Resistant to Colistin With Impaired Virulence: A Case Report From France. J. Infect. Dis. 2011, 204, 1146-1147. [CrossRef] [PubMed]

94. Fernández-Reyes, M.; Rodríguez-Falcón, M.; Chiva, C.; Pachón, J.; Andreu, D.; Rivas, L. The cost of resistance to colistin in Acinetobacter baumannii: A proteomic perspective. Proteomics 2009, 9, 1632-1645. [CrossRef] [PubMed]

95. Hraiech, S.; Roch, A.; Lepidi, H.; Atieh, T.; Audoly, G.; Rolain, J.-M.; Raoult, D.; Brunel, J.-M.; Papazian, L.; Brégeon, F. Impaired Virulence and Fitness of a Colistin-Resistant Clinical Isolate of Acinetobacter baumannii in a Rat Model of Pneumonia. Antimicrob. Agents Chemother. 2013, 57, 5120-5121. [CrossRef] [PubMed]

96. Hood, M.I.; Skaar, E.P. Nutritional immunity: Transition metals at the pathogen-host interface. Nat. Rev. Microbiol. 2012, 10, 525-537. [CrossRef] [PubMed]

97. Diaz-Ochoa, V.E.; Jellbauer, S.; Klaus, S.; Raffatellu, M. Transition metal ions at the crossroads of mucosal immunity and microbial pathogenesis. Front. Cell. Infect. Microbiol. 2014, 4, 2. [CrossRef] [PubMed]

98. Palmer, L.D.; Skaar, E.P. Transition Metals and Virulence in Bacteria. Annu. Rev. Genet. 2016, 50, 67-91. [CrossRef] [PubMed]

99. Yamamoto, S.; Okujo, N.; Sakakibara, Y. Isolation and structure elucidation of acinetobactin, a novel siderophore from Acinetobacter baumannii. Arch. Microbiol. 1994, 162, 249-254. [PubMed]

100. Antunes, L.C.S.; Imperi, F.; Towner, K.J.; Visca, P. Genome-assisted identification of putative iron-utilization genes in Acinetobacter baumannii and their distribution among a genotypically diverse collection of clinical isolates. Res. Microbiol. 2011, 162, 279-284. [CrossRef] [PubMed]

101. Mihara, K.; Tanabe, T.; Yamakawa, Y.; Funahashi, T.; Nakao, H.; Narimatsu, S.; Yamamoto, S. Identification and transcriptional organization of a gene cluster involved in biosynthesis and transport of acinetobactin, a siderophore produced by Acinetobacter baumannii ATCC 19606T. Microbiology 2004, 150, 2587-2597. [CrossRef] [PubMed]

102. Dorsey, C.W.; Tomaras, A.P.; Connerly, P.L.; Tolmasky, M.E.; Crosa, J.H.; Actis, L.A. The siderophore-mediated iron acquisition systems of Acinetobacter baumannii ATCC 19606 and Vibrio anguillarum 775 are structurally and functionally related. Microbiology 2004, 150, 3657-3667. [CrossRef] [PubMed]

103. Gaddy, J.A.; Arivett, B.A.; McConnell, M.J.; López-Rojas, R.; Pachón, J.; Actis, L.A. Role of Acinetobactin-Mediated Iron Acquisition Functions in the Interaction of Acinetobacter baumannii Strain ATCC 19606 T with Human Lung Epithelial Cells, Galleria mellonella Caterpillars, and Mice. Infect. Immun. 2012, 80, 1015-1024. [CrossRef] [PubMed]

104. Daniel, C.; Haentjens, S.; Bissinger, M.-C.; Courcol, R.J. Characterization of the Acinetobacter baumannii Fur regulator: Cloning and sequencing of the fur homolog gene. FEMS Microbiol. Lett. 1999, 170, 199-209. [CrossRef] [PubMed]

105. Zimbler, D.L.; Arivett, B.A.; Beckett, A.C.; Menke, S.M.; Actis, L.A. Functional Features of TonB Energy Transduction Systems of Acinetobacter baumannii. Infect. Immun. 2013, 81, 3382-3394. [CrossRef] [PubMed]

106. Postle, K.; Kadner, R.J. Touch and go: Tying TonB to transport. Mol. Microbiol. 2003, 49, 869-882. [CrossRef] [PubMed]

107. Häse, C.C.; Finkelstein, R.A. Bacterial extracellular zinc-containing metalloproteases. Microbiol. Rev. 1993, 57, 823-837. [PubMed]

108. Antunes, L.C.S.; Imperi, F.; Minandri, F.; Visca, P. In Vitro and In Vivo Antimicrobial Activities of Gallium Nitrate against Multidrug-Resistant Acinetobacter baumannii. Antimicrob. Agents Chemother. 2012, 56, 5961-5970. [CrossRef] [PubMed] 
109. Runci, F.; Bonchi, C.; Frangipani, E.; Visaggio, D.; Visca, P. Acinetobacter baumannii biofilm formation in Human serum and disruption by gallium. Antimicrob. Agents Chemother. 2016, 61, e01563-16. [CrossRef] [PubMed]

110. Abdalla, M.Y.; Switzer, B.L.; Goss, C.H.; Aitken, M.L.; Singh, P.K.; Britigan, B.E. Gallium Compounds Exhibit Potential as New Therapeutic Agents against Mycobacterium abscessus. Antimicrob. Agents Chemother. 2015, 59, 4826. [CrossRef] [PubMed]

111. Chitambar, C.R. Gallium and its competing roles with iron in biological systems. Biochim. Biophys. Acta 2016, 1863, 2044-2053. [CrossRef] [PubMed]

112. Niu, C.; Clemmer, K.M.; Bonomo, R.A.; Rather, P.N. Isolation and Characterization of an Autoinducer Synthase from Acinetobacter baumannii. J. Bacteriol. 2008, 190, 3386-3392. [CrossRef] [PubMed]

113. Case, R.J.; Labbate, M.; Kjelleberg, S. AHL-driven quorum-sensing circuits: Their frequency and function among the Proteobacteria. ISME J. 2008, 2, 345-349. [CrossRef] [PubMed]

114. Antunes, L.C.M.; Ferreira, R.B.R.; Buckner, M.M.C.; Finlay, B.B. Quorum sensing in bacterial virulence. Microbiology 2010, 156, 2271-2282. [CrossRef] [PubMed]

115. Patankar, A.V.; González, J.E. Orphan LuxR regulators of quorum sensing. FEMS Microbiol. Rev. 2009, 33, 739-756. [CrossRef] [PubMed]

116. Schaefer, A.L.; Lappala, C.R.; Morlen, R.P.; Pelletier, D.A.; Lu, T.-Y.S.; Lankford, P.K.; Harwood, C.S.; Greenberg, E.P. LuxR- and LuxI-Type Quorum-Sensing Circuits Are Prevalent in Members of the Populus deltoides Microbiome. Appl. Environ. Microbiol. 2013, 79, 5745-5752. [CrossRef] [PubMed]

117. Stöveken, T.; Kalscheuer, R.; Malkus, U.; Reichelt, R.; Steinbüchel, A. The Wax Ester Synthase/Acyl Coenzyme A:Diacylglycerol Acyltransferase from Acinetobacter sp. Strain ADP1: Characterization of a Novel Type of Acyltransferase. J. Bacteriol. 2005, 187, 1369-1376. [CrossRef] [PubMed]

118. Röttig, A.; Steinbüchel, A. Random mutagenesis of atfA and screening for Acinetobacter baylyi mutants with an altered lipid accumulation. Eur. J. Lipid Sci. Technol. 2013, 115, 394-404. [CrossRef]

119. Camarena, L.; Bruno, V.; Euskirchen, G.; Poggio, S.; Snyder, M. Molecular Mechanisms of Ethanol-Induced Pathogenesis Revealed by RNA-Sequencing. PLoS Pathog. 2010, 6, e1000834. [CrossRef] [PubMed]

120. Badrinarayanan, A.; Le, T.B.K.; Laub, M.T. Bacterial Chromosome Organization and Segregation. Annu. Rev. Cell Dev. Biol. 2015, 31, 171-199. [CrossRef] [PubMed]

121. Dorman, C.J.; Colgan, A.; Dorman, M.J. Bacterial pathogen gene regulation: A DNA-structure-centred view of a protein-dominated domain. Clin. Sci. 2016, 130, 1165-1177. [CrossRef] [PubMed]

122. Dillon, S.C.; Dorman, C.J. Bacterial nucleoid-associated proteins, nucleoid structure and gene expression. Nat. Rev. Microbiol. 2010, 8, 185-195. [CrossRef] [PubMed]

123. Barquist, L.; Boinett, C.J.; Cain, A.K. Approaches to querying bacterial genomes with transposon-insertion sequencing. RNA Biol. 2013, 10, 1161-1169. [CrossRef] [PubMed]

124. Gray, A.N.; Koo, B.-M.; Shiver, A.L.; Peters, J.M.; Osadnik, H.; Gross, C.A. High-throughput bacterial functional genomics in the sequencing era. Curr. Opin. Microbiol. 2015, 27, 86-95. [CrossRef] [PubMed]

125. Chaudhuri, R.R.; Morgan, E.; Peters, S.E.; Pleasance, S.J.; Hudson, D.L.; Davies, H.M.; Wang, J.; van Diemen, P.M.; Buckley, A.M.; Bowen, A.J.; et al. Comprehensive Assignment of Roles for Salmonella Typhimurium Genes in Intestinal Colonization of Food-Producing Animals. PLoS Genet. 2013, 9, e1003456. [CrossRef] [PubMed]

126. van Opijnen, T.; Camilli, A. A fine scale phenotype-genotype virulence map of a bacterial pathogen. Genome Res. 2012, 22, 2541-2551. [CrossRef] [PubMed]

127. Perry, B.J.; Yost, C.K. Construction of a mariner-based transposon vector for use in insertion sequence mutagenesis in selected members of the Rhizobiaceae. BMC Microbiol. 2014, 14, 298. [CrossRef] [PubMed]

128. Wang, N.; Ozer, E.A.; Mandel, M.J.; Hauser, A.R. Genome-Wide Identification of Acinetobacter baumannii Genes Necessary for Persistence in the Lung. mBio 2014, 5, e01163-14. [CrossRef] [PubMed]

129. Krawczyk, B.; Kur, J. In vitro interaction of the IHF-like proteins Acinetobacter junii and Proteus vulgaris with ihf sites. FEMS Microbiol. Lett. 1998, 161, 187-192. [CrossRef] [PubMed]

130. Gebhardt, M.J.; Gallagher, L.A.; Jacobson, R.K.; Usacheva, E.A.; Peterson, L.R.; Zurawski, D.V.; Shuman, H.A. Joint Transcriptional Control of Virulence and Resistance to Antibiotic and Environmental Stress in Acinetobacter baumannii. mBio 2015, 6, e01660-15. [CrossRef] [PubMed] 
131. Qi, L.S.; Larson, M.H.; Gilbert, L.A.; Doudna, J.A.; Weissman, J.S.; Arkin, A.P.; Lim, W.A. Repurposing CRISPR as an RNA-Guided Platform for Sequence-Specific Control of Gene Expression. Cell 2013, 152, 1173-1183. [CrossRef] [PubMed]

132. Storz, G.; Vogel, J.; Wassarman, K.M. Regulation by Small RNAs in Bacteria: Expanding Frontiers. Mol. Cell 2011, 43, 880-891. [CrossRef] [PubMed]

133. Papenfort, K.; Vanderpool, C.K. Target activation by regulatory RNAs in bacteria. FEMS Microbiol. Rev. 2015, 39, 362-378. [CrossRef] [PubMed]

134. Fröhlich, K.S.; Papenfort, K. Interplay of regulatory RNAs and mobile genetic elements in enteric pathogens. Mol. Microbiol. 2016, 101, 701-713. [CrossRef] [PubMed]

135. Oliva, G.; Sahr, T.; Buchrieser, C. Small RNAs, $5^{\prime}$ UTR elements and RNA-binding proteins in intracellular bacteria: Impact on metabolism and virulence. FEMS Microbiol. Rev. 2015, 39, 331-349. [CrossRef] [PubMed]

136. Papenfort, K.; Vogel, J. Small RNA functions in carbon metabolism and virulence of enteric pathogens. Front. Cell. Infect. Microbiol. 2014, 4, 91. [CrossRef] [PubMed]

137. Kröger, C.; Colgan, A.; Srikumar, S.; Händler, K.; Sivasankaran, S.K.; Hammarlöf, D.L.; Canals, R.; Grissom, J.E.; Conway, T.; Hokamp, K.; et al. An Infection-Relevant Transcriptomic Compendium for Salmonella enterica Serovar Typhimurium. Cell Host Microbe 2013, 14, 683-695. [CrossRef] [PubMed]

138. Chao, Y.; Papenfort, K.; Reinhardt, R.; Sharma, C.M.; Vogel, J. An atlas of Hfq-bound transcripts reveals $3^{\prime}$ UTRs as a genomic reservoir of regulatory small RNAs. EMBO J. 2012, 31, 4005-4019. [CrossRef] [PubMed]

139. Srikumar, S.; Kröger, C.; Hébrard, M.; Colgan, A.; Owen, S.V.; Sivasankaran, S.K.; Cameron, A.D.S.; Hokamp, K.; Hinton, J.C.D. RNA-seq Brings New Insights to the Intra-Macrophage Transcriptome of Salmonella Typhimurium. PLoS Pathog. 2015, 11, e1005262. [CrossRef] [PubMed]

140. Colgan, A.M.; Kröger, C.; Diard, M.; Hardt, W.-D.; Puente, J.L.; Sivasankaran, S.K.; Hokamp, K.; Hinton, J.C.D. The Impact of 18 Ancestral and Horizontally-Acquired Regulatory Proteins upon the Transcriptome and sRNA Landscape of Salmonella enterica serovar Typhimurium. PLoS Genet. 2016, 12, e1006258. [CrossRef] [PubMed]

141. Sharma, R.; Arya, S.; Patil, S.D.; Sharma, A.; Jain, P.K.; Navani, N.K.; Pathania, R. Identification of Novel Regulatory Small RNAs in Acinetobacter baumannii. PLoS ONE 2014, 9, e93833. [CrossRef] [PubMed]

142. Weiss, A.; Broach, W.H.; Lee, M.C.; Shaw, L.N. Towards the complete small RNome of Acinetobacter baumannii. Microb. Genomics 2016, 2. [CrossRef]

143. Vogel, J.; Luisi, B.F. Hfq and its constellation of RNA. Nat. Rev. Microbiol. 2011, 9, 578-589. [CrossRef] [PubMed]

144. Sonnleitner, E.; Romeo, A.; Bläsi, U. Small regulatory RNAs in Pseudomonas aeruginosa. RNA Biol. 2012, 9, 364-371. [CrossRef] [PubMed]

145. Sonnleitner, E.; Bläsi, U. Regulation of Hfq by the RNA CrcZ in Pseudomonas aeruginosa Carbon Catabolite Repression. PLoS Genet. 2014, 10, e1004440. [CrossRef] [PubMed]

146. Schilling, D.; Gerischer, U. The Acinetobacter baylyi hfq Gene Encodes a Large Protein with an Unusual C Terminus. J. Bacteriol. 2009, 191, 5553-5562. [CrossRef] [PubMed]

147. Chao, Y.; Vogel, J. The role of Hfq in bacterial pathogens. Curr. Opin. Microbiol. 2010, 13, 24-33. [CrossRef] [PubMed]

148. Kakoschke, T.K.; Kakoschke, S.C.; Zeuzem, C.; Bouabe, H.; Adler, K.; Heesemann, J.; Rossier, O. The RNA Chaperone Hfq Is Essential for Virulence and Modulates the Expression of Four Adhesins in Yersinia enterocolitica. Sci. Rep. 2016, 6, 29275. [CrossRef] [PubMed]

149. Feliciano, J.R.; Grilo, A.M.; Guerreiro, S.I.; Sousa, S.A.; Leitão, J.H. Hfq: A multifaceted RNA chaperone involved in virulence. Future Microbiol. 2015, 11, 137-151. [CrossRef] [PubMed]

150. Sittka, A.; Pfeiffer, V.; Tedin, K.; Vogel, J. The RNA chaperone Hfq is essential for the virulence of Salmonella typhimurium. Mol. Microbiol. 2007, 63, 193-217. [CrossRef] [PubMed]

151. Schilling, D.; Findeiß, S.; Richter, A.S.; Taylor, J.A.; Gerischer, U. The small RNA Aar in Acinetobacter baylyi: A putative regulator of amino acid metabolism. Arch. Microbiol. 2010, 192, 691-702. [CrossRef] [PubMed]

152. Massé, E.; Salvail, H.; Desnoyers, G.; Arguin, M. Small RNAs controlling iron metabolism. Curr. Opin. Microbiol. 2007, 10, 140-145. [CrossRef] [PubMed]

153. Oglesby-Sherrouse, A.G.; Murphy, E.R. Iron-responsive bacterial small RNAs: Variations on a theme. Metallomics 2013, 5, 276-286. [CrossRef] [PubMed] 
154. Nwugo, C.C.; Gaddy, J.A.; Zimbler, D.L.; Actis, L.A. Deciphering the iron response in Acinetobacter baumannii: A proteomics approach. J. Proteomics 2011, 74, 44-58. [CrossRef] [PubMed]

155. Yamada, J.; Yamasaki, S.; Hirakawa, H.; Hayashi-Nishino, M.; Yamaguchi, A.; Nishino, K. Impact of the RNA chaperone Hfq on multidrug resistance in Escherichia coli. J. Antimicrob. Chemother. 2010, 65, 853-858. [CrossRef] [PubMed]

156. Lalaouna, D.; Eyraud, A.; Chabelskaya, S.; Felden, B.; Massé, E. Regulatory RNAs Involved in Bacterial Antibiotic Resistance. PLoS Pathog. 2014, 10, e1004299. [CrossRef] [PubMed]

157. Kim, T.; Bak, G.; Lee, J.; Kim, K. Systematic analysis of the role of bacterial Hfq-interacting sRNAs in the response to antibiotics. J. Antimicrob. Chemother. 2015, 70, 1659-1668. [CrossRef] [PubMed]

158. Mizuno, T.; Chou, M.Y.; Inouye, M. A unique mechanism regulating gene expression: Translational inhibition by a complementary RNA transcript (micRNA). Proc. Natl. Acad. Sci. USA 1984, 81, 1966-1970. [CrossRef] [PubMed]

159. Papenfort, K.; Pfeiffer, V.; Mika, F.; Lucchini, S.; Hinton, J.C.D.; Vogel, J. $\sigma$ E-dependent small RNAs of Salmonella respond to membrane stress by accelerating global omp mRNA decay. Mol. Microbiol. 2006, 62, 1674-1688. [CrossRef] [PubMed]

160. Pfeiffer, V.; Papenfort, K.; Lucchini, S.; Hinton, J.C.D.; Vogel, J. Coding sequence targeting by MicC RNA reveals bacterial mRNA silencing downstream of translational initiation. Nat. Struct. Mol. Biol. 2009, 16, 840-846. [CrossRef] [PubMed]

161. Udekwu, K.I.; Darfeuille, F.; Vogel, J.; Reimegård, J.; Holmqvist, E.; Wagner, E.G.H. Hfq-dependent regulation of OmpA synthesis is mediated by an antisense RNA. Genes Dev. 2005, 19, 2355-2366. [CrossRef] [PubMed]

162. Pfeiffer, V.; Sittka, A.; Tomer, R.; Tedin, K.; Brinkmann, V.; Vogel, J. A small non-coding RNA of the invasion gene island (SPI-1) represses outer membrane protein synthesis from the Salmonella core genome. Mol. Microbiol. 2007, 66, 1174-1191. [CrossRef] [PubMed]

163. Guillier, M.; Gottesman, S.; Storz, G. Modulating the outer membrane with small RNAs. Genes Dev. 2006, 20, 2338-2348. [CrossRef] [PubMed]

164. Parker, A.; Gottesman, S. Small RNA Regulation of TolC, the Outer Membrane Component of Bacterial Multidrug Transporters. J. Bacteriol. 2016, 198, 1101-1113. [CrossRef] [PubMed]

165. Choi, C.H.; Hyun, S.H.; Lee, J.Y.; Lee, J.S.; Lee, Y.S.; Kim, S.A.; Chae, J.-P.; Yoo, S.M.; Lee, J.C. Acinetobacter baumannii outer membrane protein A targets the nucleus and induces cytotoxicity. Cell. Microbiol. 2008, 10, 309-319. [CrossRef] [PubMed]

166. Choi, C.H.; Lee, J.S.; Lee, Y.C.; Park, T.I.; Lee, J.C. Acinetobacter baumannii invades epithelial cells and outer membrane protein A mediates interactions with epithelial cells. BMC Microbiol. 2008, 8, 216. [CrossRef] [PubMed]

167. Smani, Y.; Fàbrega, A.; Roca, I.; Sánchez-Encinales, V.; Vila, J.; Pachón, J. Role of OmpA in the Multidrug Resistance Phenotype of Acinetobacter baumannii. Antimicrob. Agents Chemother. 2014, 58, 1806-1808. [CrossRef] [PubMed]

(C) 2016 by the authors; licensee MDPI, Basel, Switzerland. This article is an open access article distributed under the terms and conditions of the Creative Commons Attribution (CC-BY) license (http://creativecommons.org/licenses/by/4.0/). 